OPEN ACCESS

Edited by:

David Gregory Mottershead, Keele University, United Kingdom

Reviewed by: Susanne Elisabeth Pors, Rigshospitalet, Denmark

Mila Maidarti, University of Indonesia, Indonesia

*Correspondence: Lixia Zhu zhulixia027@163.com Lei Jin

leijintongjih@qq.com

Specialty section:

This article was submitted to Reproduction,

a section of the journal

Frontiers in Endocrinology

Received: 26 May 2020

Accepted: 06 July 2020

Published: 11 August 2020

Citation:

Yang Q, Zhu L and Jin L (2020)

Human Follicle in vitro Culture Including Activation, Growth, and Maturation: A Review of Research

Progress. Front. Endocrinol. 11:548. doi: 10.3389/fendo.2020.00548

\section{Human Follicle in vitro Culture Including Activation, Growth, and Maturation: A Review of Research Progress}

\author{
Qiyu Yang, Lixia Zhu* and Lei Jin*
}

Reproductive Medicine Center, Tongji Hospital, Tongji Medical College, Huazhong University of Science and Technology, Wuhan, China

Fertility preservation has received unprecedented attention nowadays. In addition to cryopreservation and re-implantation of embryos, oocytes, and ovarian tissue pieces, in vitro culture system for follicles/oocytes has been considered as an alternative strategy for fertility preservation. Since the metabolic dynamics and required nutrients are not entirely the same in different stages of follicular development, optimization of each culture step is needed. In this paper, literature regarding culture conditions in three steps were analyzed. Known additives in activation stage included 740Y-P, bpV(HOpic), follicle stimulating hormone $(F S H)$, human serum albumin (HSA), ITS, growth differentiation factor 9 (GDF9), bone morphogenetic protein 15 (BMP15), and cyclic adenosine monophosphate (CAMP), with different degrees of activation promotion and potential detrimental effect on DNA integrity. For isolated follicles growth stage, actin $\mathrm{A}, \mathrm{FSH}$, basic fibroblast growth factor (bFGF), estradiol were proved to improve development or proliferation. As for maturation, addition of growth hormone, melatonin, C-type natriuretic peptide (CNP), GDF9, cilostamide, or forskolin helped to regulate maturation rate or improve oocyte quality. Based on previous sequential culture system for human follicles, optimization is needed to achieve higher maturation rate and better oocyte quality, pursuant to current review, which demonstrated the effects of various additives on different stages.

Keywords: in vitro culture, human follicle, human oocyte, in vitro maturation, fertility preservation

\section{INTRODUCTION}

In recent decades, considerable progress has been made in the field of assisted reproductive technology (ART). Objectively, with improvement of the prognosis of malignant diseases and progress in ART, an increasing number of female cancer patients have the opportunity to preserve fertility through advanced technologies. Subjectively, young cancer patients are no longer satisfied simply with the continuation of life span, but become aware of their fertility needs. Therefore, fertility preservation has received unprecedented attention $(1,2)$. Thanks to current technology, part of the ovarian tissue of the women who need chemotherapy due to malignancies could be removed for cryopreservation before receiving treatment, so as to avoid the reproductive toxicity of chemotherapy drugs, and then be auto-transplanted at the end of treatment. However, the risk of re-implantation of tumor cells is faced by some patients during transplantation $(3,4)$. To solve this problem, an in vitro culture (IVC) system for follicles and oocytes has been considered as an 
alternative fertility preservation strategy without the risk of reimplanting maternal somatic tumor cells (5).

For most mammals, the formation of follicles takes place pre-natally and constitutes the basic reserve unit of female reproductive cells, which are recruited for growth throughout the female's reproductive age. Specifically, development of follicles includes (1) initiation of primordial follicle growth and development to the preantral follicle stage; (2) the formation of antral follicles; and (3) rupture of the Graafian follicle releasing a cumulus-oocyte complex (COC) at ovulation in response to the mid-cycle luteinizing hormone (LH) surge (6). The IVC system should support the development of oocytes in all stages, from activation of primordial follicle to oocyte maturation. Once the safety and effectiveness of the system are confirmed, the maximum use of the ovarian follicle reserve would be achieved, and the risk of tumor cells carried by transplanted ovarian tissue would be eliminated. Moreover, for younger patients like prepubertal girls, neither mature oocytes nor embryo cryopreservation are available. Therefore, fertility preservation may be achieved by the IVC system $(3,7,8)$.

Most follicles are in the primitive stage, and their recruitment is regulated by both endocrine factors and the ovarian internal environment $(9,10)$. During in vivo follicle growth, oocytes acquire the competence to resume meiosis, complete fertilization, and support early embryonic development. Thorough comprehension to this complicated growth procedure is essential for researchers to construct an IVC system meeting all requirements, with consideration for maintaining DNA integrity and stability $(11,12)$. In previous studies, a two-step culture system was designed for follicular development in mouse models, where the IVC oocytes were fertilized and healthy offspring were successfully obtained $(13,14)$. Similarly, mature oocytes from IVC cattle follicles were fertilized and a healthy calf was born with higher birth weight (15). These results in animal models proved the feasibility of follicular IVC. However, the inconsistency of follicular growth environment between humans and animals and challenges of applying the system to human follicles still need to be considered (16). A single research reported the multi-step IVC system for the whole course of human oocyte development, and some second meiotic metaphase (MII) oocytes were obtained (17). Since the metabolic dynamics and required nutrients are not entirely the same in different stages of follicular development, optimization of each step is needed to achieve a higher maturation rate and better oocyte quality, based on the sequential culture system. In this paper, the effects of various additives on different stages are demonstrated, and the current research progress of different stages of human follicular IVC are reviewed, respectively.

\section{INITIAL STAGE: IN VITRO ACTIVATION (IVA) OF PRIMORDIAL FOLLICLES}

Primordial follicle activation is the key initial step of oocyte development, involving the interaction of inhibitory factors, stimulating factors, and maintenance factors (18). Early studies showed that the viability of primordial follicles isolated from thawed human ovarian cortical tissues was comparable with that from fresh tissue. However, a lower survival rate was observed in IVC of isolated primordial follicles $(19,20)$. Consequently, a consensus has been reached that the culture system based on primordial follicles needs to start from human ovarian cortex tissue, not isolated primordial follicles $(17,20-23)$.

Several pathways, including the phosphatidylinositol 3 kinase (PI3K) pathway, the mechanistic target of rapamycin complex 1 (mTORC1) pathway, and the p27Kip1 (p27)-cyclin dependent kinase $(\mathrm{CDK})$ system, have been shown to regulate the activation of dormant oocytes in the mammalian ovary (18). Some components in these pathways were well-studied and used as regulatory targets for IVC optimization.

The PI3K-PTEN-AKT-FOXO3 signaling pathway is the main non-gonadotrophic growth factor signaling pathway regulating the growth and differentiation of ovarian follicles (24-27). The phosphatase and tensin homolog deleted on chromosome 10 (PTEN), as a negative regulator of PI3K, inhibits the levels of phosphatidylinositol 3,4,5-triphosphate (PIP3), leading to suppressed activation of PI3K signaling $(28,29)$. The Forkhead box O3 (FOXO3), a downstream effector, also regulates this pathway negatively and suppresses follicle activation, based on mice experiments $(24,30)$. In women with premature ovarian insufficiency (POI) or premature ovarian failure (POF), mutation in FOXO3 genes was identified and lower FOXO3a expression in ovarian tissue was detected $(31,32)$. Another component is the mTORC1, a regulator of cell growth and proliferation, involved in promoting primordial follicle activation (33). In previous studies, IVA of primordial follicles was promoted through regulating the pathway by mTOR and PI3K activator, thus improving ART outcomes of patients with POI $(26,34)$. PTEN inhibition of human ovarian tissue before auto-transplantation has been proved to significantly enhance activation of residual follicles in POI patients, and healthy baby was born (35). Noteworthily, more than $50 \%$ POI patients in this study contained no residual follicle and did not respond to the IVA agents, limiting the application of IVA procedure in infertility treatment.

During IVC of the human ovarian cortex, more primordial follicles were activated, and more secondary follicles were isolated with PTEN inhibition. Unfortunately, the survival and development of isolated follicles were poor $(26,36)$, which may be related to the effect of PTEN inhibition on the DNA repair mechanism in follicles (12). The study involving IVC of bovine ovarian cortex demonstrated that PTEN inhibition activated bovine non-growing follicles, but simultaneously increased DNA damage and reduced DNA repair response (27). Recently, a drug-free IVA method was used in infertility treatment for POI patient, leading to successful pregnancies (37). This method may eliminate the negative effect of activation agents on follicles, but it may simultaneously reduce the yield of follicles, which makes it insufficient for subsequent culture use.

The activation rate of primordial follicles varies with different culture conditions, which seems to be related to the preparation of the ovarian cortical tissue, indicating that mechanical signal was also an important influencing factor (10). The Hippo signaling pathway, which is known for its role in conserving optimal organ size via growth 
inhibition, consists of several negative growth regulators acting in a kinase cascade that ultimately phosphorylates and inactivates key Hippo signaling effectors, Yes-associated protein (YAP)/transcriptional coactivator with PDZ-binding motif (TAZ) $(26,38)$. Fragmentation of human ovarian cortical tissue can dramatically promote the activation of primordial follicles, which was proved to be the result of interruption of Hippo signal pathway. Ovarian fragmentation increased actin polymerization and disrupted Hippo signaling by decreasing pYAP levels together with increased nuclear localization of YAP, leading to increased expression of CCN growth factors and BIRC apoptosis inhibitors $(26,35)$. Intuitively, follicles at the most advanced developmental stage were observed at the periphery of the tissue, close to the section site (26). Taken together, the activation of follicles can be significantly promoted by intervening the important components of PI3K pathway, while the Hippo pathway is blocked through the fragmentation of the ovarian cortex $(9,25-27)$.

At present, common basic media for IVA include MEMalpha, Waymouth's medium, D-MEM, and McCoys 5a (17, 34, 39, 40). Different laboratories seem to choose the medium used according to their preferences and practices, because no study comparing all media exists. In an early research, two complex media ( $\alpha$-MEM and Waymouth's) were compared with a simple salt solution (EBSS), all of which contained $10 \%$ human serum. Results showed that in ovarian tissue cultured in $\alpha$ MEM, follicle growth was significantly greater and development was improved compared to that seen in follicles cultured with Waymouth's medium. A proportion of follicles cultured with both $\alpha$-MEM and Waymouth's media reached secondary stages on day 10 of culture. However, only follicles cultured with $\alpha$ MEM reached preantral stages until days 15 (41). Both media contained amino acids, vitamins, and inorganic salts, but $\alpha$-MEM has some unique components, including alanine, serine, lipoic acid, ribonucleosides, and deoxyribonucleosides. Meanwhile, the vitamin concentration in $\alpha$-MEM are higher than that in Waymouth's medium. Unfortunately, the study did not discuss the specific reason of different effects of the two media. It would be interesting to investigate how various nutrients in different media act on primordial follicle IVA.

Further understanding of effect of specific factors on the activation process was another hot topic to improve the quantity and quality of IVC follicles. For example, on the basis of $\alpha$ MEM, the culture system with human albumin and ITS (insulin, transferrin, selenium) is more favorable to the activation and development of human follicles, leaving less atretic follicles, than that with serum alone. And the addition of follicle stimulating hormone (FSH) to the media greatly reduces atresia and increases follicle diameter simultaneously (41). However, the findings in different reports could be contradictory. One study in 2005 showed that human follicular recruitment and activation were promoted in culture media with $300 \mathrm{ng} / \mathrm{ml}$ anti-Mullerian hormone (AMH) (40), while another research in 2006 disclosed the inhibitory effect of $100 \mathrm{ng} / \mathrm{ml} \mathrm{AMH}$ on human follicles activation (42). The reason for the difference between findings was unclear. It is possible that AMH influences primordial follicle activation in a dose-dependent manner as shown in a study using an ovine pre-pubertal ovarian cortex culture system (43). In fact, no unified standard for the timing and dosage of important additives has been developed. Currently, a consensus has been reached that the interaction between oocytes and somatic cells is essential for the activation and development of follicles (18). The intercellular communication is influenced by the members of TGF beta superfamily, especially the oocyte specific factors: growth differentiation factor (GDF)- 9 and bone morphogenetic protein (BMP)-15 (44). In human follicles, GDF-9 and BMP15 are expressed both in oocytes and cumulus granulosa cells. The increase of mRNA levels in cumulus cells is related to the oocyte maturity and fertilization rate (45), and the addition of GDF-9 or BMP-15 in IVC system can promote the activation of human primordial follicles, with seemingly more beneficial effects of GDF9 (46). Other factors, such as basic fibroblast growth factor (bFGF), kit ligand (KITL), keratinocyte growth factor (KGF), leukemia inhibitory factor (LIF), stem cell factor (SCF), vascular endothelial growth factor (VEGF), and cyclic adenosine monophosphate (cAMP), have also been proved to improve the activation and survival of cultured follicles in vitro (47-49). Shown in Table 1.

\section{DEVELOPMENT STAGE: IN VITRO GROWTH (IVG) OF SEPARATED SECONDARY FOLLICLES}

As mentioned above, the culture system based on primordial follicles needs to start from human ovarian cortex tissue, in which the activated follicles are capable of developing to secondary stage, with multi-layer granular cells. However, further development will be inhibited if secondary follicles are not separated from the cortex $(17,23,39)$. Secondary follicles can be separated by an enzymatic method, mechanical method or combination of the two methods. Mechanical isolation, with a fine syringe needle, has been commonly used for follicle isolation $(17,50,51)$. This method preserves the natural follicular morphology, maintaining an intact theca cell layer and a normal basement membrane. However, it is inevitably laborious and inefficient (52), especially for denser human ovarian tissue. Enzymatic follicle isolation typically involves collagenase and DNase enzymolysis, by which the COCs were obtained from mice ovaries, and offsprings were produced following appropriate culture, indicating that intact follicle structure is not an absolute requirement during follicle IVC (53). A later study on molecular level showed that theca cells of mechanically-isolated secondary follicles induced the expression of IGF1 and promoted follicular growth in mice, while many follicles with theca cells still showed no growth during culture (54). It seems that theca cells affect follicular development to some extent, but may not be the only and necessary factor, as long as migration of granulosa cells from oocyte could be minimized (53). Interestingly, one study even demonstrated that although incubated with enzymes for $1 \mathrm{~h}$, most enzymatically isolated follicles contained more theca cells compared with mechanically isolated follicles, which is contrary to our general thought (55). However, the influence of the operating technology of the experimenters cannot be excluded. 
TABLE 1 | Reported additives in human follicle in vitro activation stage.

\begin{tabular}{|c|c|c|c|c|c|}
\hline Additives & Species & Dose & Mechanism & Effect & Detection method \\
\hline $\begin{array}{l}740 Y-P \\
(26,34,35)\end{array}$ & Human & $150 \mu \mathrm{g} / \mathrm{ml}$ & PI3K/AKT activator & $\begin{array}{l}\text { More follicles activated, no survival } \\
\text { difference; } \\
\text { Increase in p-PTEN levels and Akt } \\
\text { and rpS6 phosphorylation; } \\
\text { Higher serum AMH; } \\
\text { Healthy baby achieved. }\end{array}$ & $\begin{array}{l}\text { Histological analysis; } \\
\text { TUNEL apoptosis assay; } \\
\text { Immunohistochemistry for } \\
\text { Ki67, GDF9, rtPCR for TSC1, } \\
\text { LATS1, Kit Ligand; E2 and } \\
\text { AMH assay. }\end{array}$ \\
\hline $\begin{array}{l}\text { bpV(HOpic) } \\
(26,34,35)\end{array}$ & Human & $30 \mu \mathrm{M}$ & PTEN inhibitor & & \\
\hline bpV (HOpic) (36) & Human & $1 \mu \mathrm{M}$ & PTEN inhibitor & $\begin{array}{l}\text { More follicles activated, with limited } \\
\text { growth and reduced survival of } \\
\text { isolated follicles. }\end{array}$ & $\begin{array}{l}\text { Histological analysis; } \\
\text { Immunohistochemistry for } \\
\text { FOXO3. }\end{array}$ \\
\hline rhAMH (40) & Human & $300 \mathrm{ng} / \mathrm{ml}$ & $\begin{array}{l}\text { May rescue some follicles } \\
\text { from entering atresia }\end{array}$ & $\begin{array}{l}\text { Enhance follicles recruitment, } \\
\text { survival and growth. }\end{array}$ & Histological analysis \\
\hline rrAMH (42) & Human & $100 \mathrm{ng} / \mathrm{ml}$ & $\begin{array}{l}\text { Act as a negative paracrine } \\
\text { feedback signal }\end{array}$ & $\begin{array}{l}\text { Suppress the initiation of the growth } \\
\text { of primordial follicles, without } \\
\text { detrimental effect on viability or } \\
\text { follicle density. }\end{array}$ & Histological analysis \\
\hline FSH (41) & Human & $\begin{array}{l}300 \\
\mathrm{mlU} / \mathrm{ml}\end{array}$ & $\begin{array}{l}\text { Prevent apoptotic atresia; } \\
\text { Mitogenic function }\end{array}$ & $\begin{array}{l}\text { Reduce the proportion of atretic } \\
\text { follicles; Increase follicle size and } \\
\text { healthy follicles. }\end{array}$ & Histological analysis \\
\hline HSA+ITS (41) & Human & $\begin{array}{l}2.5 \% \mathrm{HSA} \\
1 \% \mathrm{ITS}^{\star}\end{array}$ & $\begin{array}{l}\text { Promote cell proliferation; Act } \\
\text { as free-radical scavengers. }\end{array}$ & $\begin{array}{l}\text { Reduce the proportion of atretic } \\
\text { follicles; Increase follicle size and } \\
\text { healthy follicles. }\end{array}$ & Histological analysis \\
\hline GDF9 (46) & Human & $\begin{array}{l}10 \mathrm{ng} / \mathrm{ml} \\
100 \mathrm{ng} / \mathrm{ml}\end{array}$ & $\begin{array}{l}\text { BMP15 activates the } \\
\text { intracellular signal-mediated } \\
\text { pathways } \\
\text { Smad1, Smad5, and Smad8; }\end{array}$ & $\begin{array}{l}\text { More follicles activated; } \\
\text { More follicles activated; increase } \\
\text { PCNA expression; }\end{array}$ & $\begin{array}{l}\text { Histological analysis; } \\
\text { Immunohistochemistry }\end{array}$ \\
\hline BMP15 (46) & Human & $\begin{array}{l}10 \mathrm{ng} / \mathrm{ml} \\
100 \mathrm{ng} / \mathrm{ml}\end{array}$ & $\begin{array}{l}\text { GDF9 } \\
\text { activates Smad2 and Smad3 }\end{array}$ & $\begin{array}{l}\text { More follicles activated; } \\
\text { Increase PCNA expression; }\end{array}$ & \\
\hline CAMP (48) & Human & $0.5 \mathrm{mM}$ & $\begin{array}{l}\text { Induce formation of the FSH } \\
\text { receptor, as an intracellular } \\
\text { second messenger }\end{array}$ & More follicles activated; & Histological analysis \\
\hline
\end{tabular}

*1\% ITS includes $10 \mathrm{mg} / \mathrm{ml}$ insulin, $5.5 \mathrm{mg} / \mathrm{ml}$ transferrin, and $6.7 \mathrm{ng} / \mathrm{ml}$ sodium selenite.

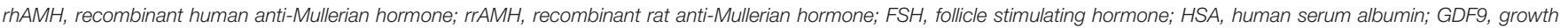
differentiation factor 9; BMP15, bone morphogenetic protein 15; CAMP, cyclic adenosine monophosphate.

Most recently, a research compared four isolation methods (two mechanical and two enzymatic) with mice, concluding that mechanical methods were preferable, with better follicular growth, survival, and MII rate. In addition, mincing isolation with a cell dissociation kit (SigmaAldrich) was more effective than conventional mechanical isolation (56). Overall, there is no one method that is absolutely superior to the others. And considering the difference between ovaries of mice and humans, both methods need to be improved and well-designed comparative researches on human samples are required.

IVG of isolated secondary follicles also depends on oocyte somatic interaction (57). At this stage, addition of activin and low-dose FSH, based on IVA medium, can help to maintain the intercellular connection, improve the quality of oocytes and promote the formation of antrum, which has been verified in dog, bovine, and human experiments $(17,39,58,59)$. Addition of $200 \mathrm{ng} / \mathrm{ml} \mathrm{bFGF}$ in IVG medium also promotes the development of human ovarian early follicles (60), as shown in Table 2.

In addition to optimizing the composition of culture medium, the physical environment of isolated follicle culture is also widely concerned. Conventional planar 2D culture plates may destroy the connection between human oocytes and granulosa cells, and inhibit the development of follicles (61). Therefore, some 3D culture systems were established to support the IVG of pre-antral follicles, and tissue engineering technology was also applied to this stage (62). Human preantral follicles can be encapsulated in bio-matrices such as alginate to complete growth and development in vitro (63). Alginate is a polysaccharide found in algal cell walls, which can form rigid and controllable gel. Studies have shown poor growth of mouse follicles embedded in $1 \%$ alginate gels (64), while $0.5 \%$ alginate gel supports the growth of human oocytes well (63). The research using microfluidic technology to encapsulate follicles also proved the function of mechanical heterogeneity in follicle development and ovulation (65). This indicated the effect of rigidity of the gel and the significance of balancing flexibility of the gel to accommodate cell proliferation with its rigidity to avoid collapse of the follicle structure (66). Other scaffolds such as de-cellularised ovarian tissue and 3D microporous scaffolds were also applied to support human pre-antral follicle growth $(67,68)$. 
TABLE 2 | Reported additives in human follicle in vitro growth stage.

\begin{tabular}{|c|c|c|c|c|c|}
\hline Additives & Species & Dose & Mechanism & Effect & Detection method \\
\hline $\begin{array}{l}\text { Actin A } \\
(39)\end{array}$ & Human & $100 \mathrm{ng} / \mathrm{ml}$ & $\begin{array}{l}\text { Regulate granulosa cell growth and } \\
\text { differentiation }\end{array}$ & $\begin{array}{l}\text { Increase follicles diameter; } \\
\text { Higher estradiol secretion; } \\
\text { More healthy follicles }\end{array}$ & $\begin{array}{l}\text { Histological analysis; } \\
\text { Diameter measurements; } \\
\text { Detection of estradiol in culture } \\
\text { media by enzyme immunoassay }\end{array}$ \\
\hline FSH (59) & Human & $1.5 \mathrm{U} / \mathrm{ml}$ & Increase E2 production & $\begin{array}{l}\text { Promote follicle antrum formation } \\
\text { and growth }\end{array}$ & $\begin{array}{l}\text { Histological analysis; } \\
\text { E2 assay. }\end{array}$ \\
\hline bFGF (60) & Human & $200 \mathrm{ng} / \mathrm{ml}$ & $\begin{array}{l}\text { Promote GC proliferation, suppress } \\
\text { apoptosis in preantral follicles, and } \\
\text { enhance early follicle cell } \\
\text { differentiation. }\end{array}$ & $\begin{array}{l}\text { Higher diameter and survival rate, } \\
\text { with good viability. }\end{array}$ & $\begin{array}{l}\text { Histological analysis; } \\
\text { Confocal analysis. }\end{array}$ \\
\hline
\end{tabular}

FSH, follicle stimulating hormone; bFGF, basic fibroblast growth factor.

In previous multi-step IVC system of human follicles, isolated secondary follicles were directly placed in a 96 well V-bottomed plate, without any extracellular matrix or scaffold. Sixty-two percent of the follicles completed the process of growth, differentiation and follicle antrum formation, but only $8 \%$ of the follicles finally reached MII stage (17). Another team's research showed that the follicles encapsulated in alginate can reach $110 \mu \mathrm{m}$ in diameter after 30 days of culture, while the oocytes in these follicles cannot reach MII stage (63). Considering that human immature follicles gradually move from the rigid collagen-dense cortex zone to the less dense perimedullary region as they grow $(69,70)$, this team released a portion of follicles from the alginate hydrogels at antral stage, and then continued the culture in low-attachment plates for up to 40 days in further study. Results showed that follicles cultured with only alginate encapsulation produced oocytes that either remained in the germinal vesicle (GV) stage or degenerated, while $20 \%$ (four out of 20) of follicles cultured using the two-step strategy produced meiotic competent MII oocytes (61). In the future, more research is needed to compare different culture environments to find out which one best supports the development of follicles in vitro.

\section{MATURATION STAGE: IN VITRO MATURATION (IVM) OF OOCYTES}

Since human immature oocytes were cultured by IVM technology, resulting in a live birth after fertilization in 1991 (71), many studies regarding the establishment and optimization of the IVM system have been reported. The source of oocytes selected for IVM seems to be a crucial factor as the successful maturation of immature oocytes is lower than that of oocytes obtained from stimulated ovaries $(72,73)$. The developmental competence of IVG derived oocytes is different from that of natural or controlled ovulation cycle derived oocytes. Therefore, if IVG is to be used in clinical practice, IVM conditions need to be optimized (74).

In 2008, Telfer et al. developed a two-step culture system, which initially demonstrated that individual human pre-antral follicles grown in vitro from the primordial stage, within human ovarian cortical strips, can be isolated and have the potential to grow to the antral stage (39). From then, scientists have been working on bridging the gap between IVG of follicles and IVM of oocytes. The oocytes produced by IVG need to be transferred to the maturation medium when they reach a certain stage, so as to complete the final meiotic resumption and maturation. In 2015 , a study comparing alginate encapsulation culture and twostep culture of isolated follicles revealed that the diameters of oocytes that reached the MII stage was not significantly different from that of oocytes that remained in GV stage, indicating that the oocyte meiotic competence could be achieved although the terminal follicle size cannot reach the size of preovulatory follicles in vivo (61). In the later modified multi-step IVC system, follicular antrum formation was observed within 6-8 days of isolated follicle culture, and at the time COCs were removed for subsequent culture, without waiting for the follicle diameter to increase to the preovulatory follicle level. After IVM, oocytes with a diameter over $100 \mu \mathrm{m}$ were obtained and few of them developed to MII stage (17). These results indicated that a more direct and efficient IVC process could be achieved based on the development of oocytes rather than the diameter of follicles.

However, the maturation rates of IVG derived oocytes were still not ideal. In the most recent multi-step culture system, 32 COC from IVG were selected for IVM, and nine oocytes emitted polar bodies after $24 \mathrm{~h}$ of maturation (17). Optimization is required not only for the IVM stage, but also for the whole culturing course. Nevertheless, most of the studies focused merely on the maturation stage of the oocytes, so the oocytes used in the experiments were obtained mainly from immature oocytes in the $\mathrm{COH}$ cycle, while IVG derived oocyte maturation was less reported. While almost all the literature on IVM optimization was based on oocytes harvested from stimulated ovaries, a review of the results of these literature still helps to optimize IVM following IVG.

Common basic media for IVM include $\alpha$-MEM, SAGE, TCM$199(17,61,75)$, although which medium is better for oocyte maturation is still uncertain. To explore the best conditions of IVM, a good understanding of the mechanism of oocyte maturation is needed. cAMP plays a crucial role in regulating oocyte maturation. The granulosa cells in the outer layer contain C-type natriuretic peptide (CNP), while the natriuretic peptide receptor (NPR2) is expressed in the cumulus cells around the oocytes. The paracrine factors of oocytes promote the activation of NPR2 in the cumulus cells, and the CNP binds to the 
TABLE 3 | Reported additives in human follicle in vitro maturation stage.

\begin{tabular}{|c|c|c|c|c|c|}
\hline Additives & Species & Dose & Mechanism & Effect & Detection method \\
\hline Melatonin (75) & Human & $\begin{array}{l}10 \\
\mu \mathrm{mol} / \mathrm{L}\end{array}$ & $\begin{array}{l}\text { Maintain the mitochondrial oxidative } \\
\text { phosphorylation function in the } \\
\text { oocytes by effectively inhibiting } \\
\text { environmental stress, providing } \\
\text { sufficient ATP for subsequent } \\
\text { embryo development. }\end{array}$ & $\begin{array}{l}\text { Increased high-quality blastocyst } \\
\text { formation rate, with low aneuploidy } \\
\text { rate. }\end{array}$ & $\begin{array}{l}\text { Blastocyst grading and examination } \\
\text { of aneuploidy; } \\
\text { Single-cell RNA-sequence analysis; } \\
\text { Detection of ROS and calcium } \\
\text { levels in human oocytes; } \\
\text { Mitochondrial function assay in } \\
\text { human oocytes }\end{array}$ \\
\hline $\mathrm{GH}(81)$ & Human & $200 \mathrm{ng} / \mathrm{ml}$ & $\begin{array}{l}\text { Accelerate meiotic progression, } \\
\text { balance redox homeostasis of } \\
\text { cellular environment, and promote } \\
\text { oocyte developmental competence }\end{array}$ & $\begin{array}{l}\text { Promote maturation of human } \\
\text { oocytes }\end{array}$ & $\begin{array}{l}\text { Oocyte RNA Sequencing; } \\
\text { Real-Time PCR for Validation }\end{array}$ \\
\hline CNP (80) & Human & $25 \mathrm{nM}$ & $\begin{array}{l}\text { Binds the Natriuretic peptide } \\
\text { receptor } 2 \text { (NPR2), induces the } \\
\text { production of cGMP }\end{array}$ & Increase the meiotic maturation rate & $\begin{array}{l}\text { Evaluation of blastocyst yield; } \\
\text { Documentation of aneuploidy rate } \\
\text { in blastocysts; Assessment of } \\
\text { cumulus-oocyte TZPs; Evaluation of } \\
\text { chromatin configuration in GV } \\
\text { oocytes }\end{array}$ \\
\hline GDF9 (82) & Human & $200 \mathrm{ng} / \mathrm{mL}$ & Promote cumulus expansion & $\begin{array}{l}\text { Increase the embryo formation rate } \\
\text { and blastocyst viability }\end{array}$ & $\begin{array}{l}\text { Assessment of maturation, } \\
\text { fertilization, embryo formation, } \\
\text { blastocyst formation rate, and } \\
\text { blastocyst viability (by Propidium } \\
\text { iodide/Hoechst staining). }\end{array}$ \\
\hline $\begin{array}{l}\text { Cilostamide } \\
(79)\end{array}$ & Human & $20 \mu \mathrm{M}$ & PDE3 specific inhibitor & $\begin{array}{l}\text { Positively influence oocyte } \\
\text { developmental competence by } \\
\text { exhibiting a synergistic effect on the } \\
\text { prevention of gap junction } \\
\text { communication loss and } \\
\text { resumption of meiosis }\end{array}$ & $\begin{array}{l}\text { Intercellular gap junction } \\
\text { communication and maturational } \\
\text { status were examined by } \\
\text { fluorophotometry; }\end{array}$ \\
\hline Forskolin (79) & Human & $50 \mu \mathrm{M}$ & Adenylate cyclase activator & & \\
\hline
\end{tabular}

$\mathrm{GH}$, growth hormone; CNP, C-type natriuretic peptide.

NPR2 receptor in the cumulus cells to produce cyclic guanosine monophosphate (cGMP), which enters the oocytes through gap junctions, inhibits the activity of phosphodiesterase (PDE3A), maintains a high level of cAMP, and thus keeps the meiosis arrest of oocytes. When PDE3A is activated by LH, the cAMP level in oocytes would be down-regulated, resulting in resumption from meiotic arrest of the immature oocytes in the GV stage or the first meiotic metaphase. Subsequently, the oocytes reach MII stage and complete maturation (76).

Accordingly, synchronization of nuclear and cytoplasmic maturation processes within the oocyte could be achieved through controlling COC cAMP level. Experiments showed that artificial regulation of meiotic resumption by cAMP elevating agents improved subsequent human oocyte developmental competence $(77,78)$. Combined treatment of cilostamide (PDE3 specific inhibitor) and forskolin (adenylate cyclase activator) positively influences the IVM oocyte developmental competence (79). Using CNP in the medium increased the meiotic maturation rate of IVM human oocytes (80). Some other factors also have been proved to promote oocyte maturation or benefit subsequent processes (Table 3). The addition of GDF9 had no effect on maturation rate, while it significantly enhanced fertilization, embryo formation, and viability rates of blastocysts (82). And the growth hormone (GH) was applied to improve the IVM maturation rate of human oocytes (81). More specifically, melatonin had no significant effect on the maturation rate of oocytes, while it increased the blastocyst formation rate after fertilization from 24.5 to $49.3 \%$, by protecting mitochondrial function (75). High-glucose concentrations altered DNA methylation levels of Peg3 and adiponectin in human IVM oocytes (83).

\section{CONCLUSION AND PROSPECTS}

Based on the animal experiments and the basic human follicle IVC system established, the concept of achieving MII oocytes from human primordial follicles through IVC to obtain offspring after in vitro fertilization (IVF) seems promising. However, currently, the clinical use of human follicular IVC systems is still limited by low MII rates, ambiguous fertilization capacities, and unknown safety. Based on the information provided by this review, future studies may focus on the following: (1) IVA: clarifying the safe concentration and safe exposure duration of existing activators, or further exploring the drugfree activation; (2) IVG: exploring the optimal method and timing of human follicle isolation, and developing the 3dimension system, combined with bioengineering technology, such as microfluidic technology $(84,85)$, to simulate the in vivo follicular development environment; (3) IVM: establishing a whole-course culture system to improve the maturation rate and developmental potential of IVG-derived oocytes, in addition to studying this stage alone; (4) to explore the fertilization ability 
and embryo developmental potential of mature oocytes obtained by IVC within ethical agreements.

In conclusion, IVC is likely to provide an ideal option for the fertility preservation of young cancer patients and for the infertility treatment of patients with POI or POF in the future. However, before this technology is applied to clinical practice, a large number of studies are required to optimize each stage of follicular development in vitro, establishing a relatively unified, standard, efficient and safe culture system.

\section{REFERENCES}

1. Siegel RL, Miller KD, Jemal A. Cancer statistics, 2020. CA Cancer J Clin. (2020) 70:7-30. doi: 10.3322/caac. 21590

2. Anderson RA, Baird DT. The development of ovarian tissue cryopreservation in Edinburgh: translation from a rodent model through validation in a large mammal and then into clinical practice. Acta Obstet Gynecol Scand. (2019) 98:545-9. doi: 10.1111/aogs.13560

3. Anderson RA, Wallace WHB, Telfer EE. Ovarian tissue cryopreservation for fertility preservation: clinical and research perspectives. Hum Reprod Open. (2017) 2017:hox001. doi: 10.1093/hropen/hox001

4. Dolmans MM, Luyckx V, Donnez J, Andersen CY, Greve T. Risk of transplanting malignant cells with transplanted frozen-thawed ovarian tissue. Fertil Steril. (2013) 99:1514-22. doi: 10.1016/j.fertnstert.2013.03.027

5. de Vos M, Smitz J, Woodruff TK. Fertility preservation in women with cancer. Lancet. (2014) 384:1302-10. doi: 10.1016/S0140-6736(14)60834-5

6. Telfer EE, Zelinski MB. Ovarian follicle culture: advances and challenges for human and nonhuman primates. Fertil Steril. (2013) 99:1523-33. doi: 10.1016/j.fertnstert.2013.03.043

7. Telfer EE. Future developments: in vitro growth (IVG) of human ovarian follicles. Acta Obstet Gynecol Scand. (2019) 98:653-8. doi: 10.1111/aogs.13592

8. Anderson RA, Mitchell RT, Kelsey TW, Spears N, Telfer EE, Wallace WH. Cancer treatment and gonadal function: experimental and established strategies for fertility preservation in children and young adults. Lancet Diabetes Endocrinol. (2015) 3:556-67. doi: 10.1016/S2213-8587(15)00039-X

9. Hsueh AJ, Kawamura K, Cheng Y, Fauser BC. Intraovarian control of early folliculogenesis. Endocr Rev. (2015) 36:1-24. doi: 10.1210/er.2014-1020

10. Shah JS, Sabouni R, Cayton Vaught KC, Owen CM, Albertini DF, Segars JH. Biomechanics and mechanical signaling in the ovary: a systematic review. $J$ Assist Reprod Genet. (2018) 35:1135-48. doi: 10.1007/s10815-018-1180-y

11. Anderson RA, Telfer EE. Being a good egg in the 21st century. Br Med Bull. (2018) 127:83-9. doi: 10.1093/bmb/ldy023

12. Martin JH, Aitken RJ, Bromfield EG, Nixon B. DNA damage and repair in the female germline: contributions to ART. Hum Reprod Update. (2019) 25:180-201. doi: 10.1093/humupd/dmy040

13. Eppig JJ, O’Brien MJ. Development in vitro of mouse oocytes from primordial follicles. Biol Reprod. (1996) 54:197-207. doi: 10.1095/biolreprod54.1.197

14. O’Brien MJ, Pendola JK, Eppig JJ. A revised protocol for in vitro development of mouse oocytes from primordial follicles dramatically improves their developmental competence. Biol Reprod. (2003) 68:1682-6. doi: 10.1095/biolreprod.102.013029

15. Hirao Y, Naruse K, Kaneda M, Somfai T, Iga K, Shimizu M, et al. Production of fertile offspring from oocytes grown in vitro by nuclear transfer in cattle. Biol Reprod. (2013) 89:57. doi: 10.1095/biolreprod.113.109439

16. Herta AC, Lolicato F, Smitz JEJ. In vitro follicle culture in the context of IVF. Reproduction. (2018) 156:F59-73. doi: 10.1530/REP-18-0173

17. McLaughlin M, Albertini DF, Wallace WHB, Anderson RA, Telfer EE. Metaphase II oocytes from human unilaminar follicles grown in a multi-step culture system. Mol Hum Reprod. (2018) 24:135-42. doi: 10.1093/molehr/gay002

18. Zhang $\mathrm{H}$, Liu K. Cellular and molecular regulation of the activation of mammalian primordial follicles: somatic cells initiate follicle activation in adulthood. Hum Reprod Update. (2015) 21:779-86. doi: 10.1093/humupd/dmv037

\section{AUTHOR CONTRIBUTIONS}

All authors have contributed to the preparation of this manuscript, read, and approved the manuscript.

\section{FUNDING}

This work was supported by research grants from the National Key Research and Development Project (2018YFC1002103).

19. Oktay K, Nugent D, Newton H, Salha O, Chatterjee P, Gosden RG. Isolation and characterization of primordial follicles from fresh and cryopreserved human ovarian tissue. Fertil Steril. (1997) 67:481-6. doi: 10.1016/S0015-0282(97)80073-8

20. Hovatta O, Silye R, Abir R, Krausz T, Winston RM. Extracellular matrix improves survival of both stored and fresh human primordial and primary ovarian follicles in long-term culture. Hum Reprod. (1997) 12:1032-6. doi: 10.1093/humrep/12.5.1032

21. Picton HM, Gosden RG. In vitro growth of human primordial follicles from frozen-banked ovarian tissue. Mol Cell Endocrinol. (2000) 166:27-35. doi: 10.1016/S0303-7207(00)00294-X

22. Gosden RG, Mullan J, Picton HM, Yin H, Tan SL. Current perspective on primordial follicle cryopreservation and culture for reproductive medicine. Hum Reprod Update. (2002) 8:105-10. doi: 10.1093/humupd/8.2.105

23. Anderson RA, McLaughlin M, Wallace WH, Albertini DF, Telfer EE. The immature human ovary shows loss of abnormal follicles and increasing follicle developmental competence through childhood and adolescence. Hum Reprod. (2014) 29:97-106. doi: 10.1093/humrep/det388

24. Reddy P, Liu L, Adhikari D, Jagarlamudi K, Rajareddy S, Shen Y, et al. Oocytespecific deletion of Pten causes premature activation of the primordial follicle pool. Science. (2008) 319:611-3. doi: 10.1126/science.1152257

25. Li J, Kawamura K, Cheng Y, Liu S, Klein C, Liu S, et al. Activation of dormant ovarian follicles to generate mature eggs. Proc Natl Acad Sci USA. (2010) 107:10280-4. doi: 10.1073/pnas.1001198107

26. Grosbois J, Demeestere I. Dynamics of PI3K and hippo signaling pathways during in vitro human follicle activation. Hum Reprod. (2018) 33:1705-14. doi: 10.1093/humrep/dey250

27. Maidarti M, Clarkson YL, McLaughlin M, Anderson RA, Telfer EE. Inhibition of PTEN activates bovine non-growing follicles in vitro but increases DNA damage and reduces DNA repair response. Hum Reprod. (2019) 34:297-307. doi: 10.1093/humrep/dey354

28. Salmena L, Carracedo A, Pandolfi PP. Tenets of PTEN tumor suppression. Cell. (2008) 133:403-14. doi: 10.1016/j.cell.2008.04.013

29. Carolyn A Worby, Jack E Dixon. PTEN. Annu Rev Biochem. (2014) 83:641-69. doi: 10.1146/annurev-biochem-082411-113907

30. Castrillon DH, Miao L, Kollipara R, Horner JW, DePinho RA. Suppression of ovarian follicle activation in mice by the transcription factor Foxo3a. Science. (2003) 301:215-8. doi: 10.1126/science.1086336

31. Thanatsis N, Kaponis A, Koika V, Georgopoulos NA, Decavalas GO. Reduced Foxo3a, FoxL2, and p27 mRNA expression in human ovarian tissue in premature ovarian insufficiency. Hormones. (2019) 18:409-15. doi: 10.1007/s42000-019-00134-4

32. Wendy J Watkins, Alexandra J Umbers, Kathryn J Woad, Sarah E Harris, Ingrid M Winship, Ksenija Gersak, et al. Mutational screening of FOXO3A and FOXO1A in women with premature ovarian failure. Fertil Steril. (2006) 86:1518-21. doi: 10.1016/j.fertnstert.2006.03.054

33. Adhikari D, Liu K. mTOR signaling in the control of activation of primordial follicles. Cell Cycle. (2010) 9:1673-74. doi: 10.4161/cc.9.9.11626

34. Suzuki N, Yoshioka N, Takae S, Sugishita Y, Tamura M, Hashimoto S, et al. Successful fertility preservation following ovarian tissue vitrification in patients with primary ovarian insufficiency. Hum Reprod. (2015) 30:608-15. doi: 10.1093/humrep/deu353

35. Kawamura K, Cheng Y, Suzuki N, Deguchi M, Sato Y, Takae S, et al. Hippo signaling disruption and Akt stimulation of ovarian follicles 
for infertility treatment. Proc Natl Acad Sci USA. (2013) 110:17474-9. doi: $10.1073 /$ pnas. 1312830110

36. McLaughlin M, Kinnell HL, Anderson RA, Telfer EE. Inhibition of phosphatase and tensin homologue (PTEN) in human ovary in vitro results in increased activation of primordial follicles but compromises development of growing follicles. Mol Hum Reprod. (2014) 20:736-44. doi: 10.1093/molehr/gau037

37. Ferreri J, Fàbregues F, Calafell JM, Solernou R, Borrás A, Saco A, et al. Drugfree In-vitro activation of follicles and fresh tissue autotransplantation as a therapeutic option in patients with primary ovarian insufficiency. Reprod Biomed Online. (2020) 40:254-60. doi: 10.1016/j.rbmo.2019.11.009

38. Badouel C, McNeill H. SnapShot: the hippo signaling pathway. Cell. (2011) 145:484.e1. doi: 10.1016/j.cell.2011.04.009

39. Telfer EE, McLaughlin M, Ding C, Thong KJ. A two-step serum-free culture system supports development of human oocytes from primordial follicles in the presence of activin. Hum Reprod. (2008) 23:1151-8. doi: 10.1093/humrep/den070

40. Schmidt KL, Kryger-Baggesen N, Byskov AG, Andersen CY. Anti-Mullerian hormone initiates growth of human primordial follicles in vitro. Mol Cell Endocrinol. (2005) 234:87-93. doi: 10.1016/j.mce.2004.12.010

41. Wright CS, Hovatta O, Margara R, Trew G, Winston RM, Franks S, et al. Effects of follicle-stimulating hormone and serum substitution on the Invitro growth of human ovarian follicles. Hum Reprod. (1999) 14:1555-62. doi: 10.1093/humrep/14.6.1555

42. Carlsson IB, Scott JE, Visser JA, Ritvos O, Themmen AP, Hovatta O. AntiMüllerian hormone inhibits initiation of growth of human primordial ovarian follicles in vitro. Hum Reprod. (2006) 21:2223-7. doi: 10.1093/humrep/del165

43. Bertoldo MJ, Bernard J, Duffard N, Tsikis G, Alves S, Calais L, et al. Inhibitors of c-Jun phosphorylation impede ovine primordial follicle activation. Mol. Hum. Reprod. (2016) 22:338-49. doi: 10.1093/molehr/gaw012

44. Sanfins A, Rodrigues P, Albertini DF. GDF-9 and BMP-15 direct the follicle symphony. J Assist Reprod Genet. (2018) 35:1741-50. doi: 10.1007/s10815-018-1268-4

45. Li Y, Li RQ, Ou SB, Zhang NF, Ren L, Wei LN, et al. Increased GDF9 and BMP15 mRNA levels in cumulus granulosa cells correlate with oocyte maturation, fertilization, and embryo quality in humans. Reprod Biol Endocrinol. (2014) 12:81. doi: 10.1186/1477-7827-12-81

46. Kedem A, Fisch B, Garor R, Ben-Zaken A, Gizunterman T, Felz C, et al. Growth differentiating factor 9(GDF9) and bone morphogenetic protein 15 both activate development of human primordial follicles in vitro, with seemingly more beneficial effects of GDF9. J Clin Endocrinol Metab. (2011) 96:E1246-54. doi: 10.1210/jc.2011-0410

47. Bertoldo MJ, Walters KA, Ledger WL, Gilchrist RB, Mermillod P, Locatelli Y. In-vitro regulation of primordial follicle activation: challenges for fertility preservation strategies. Reprod Biomed Online. (2018) 36:491-9. doi: 10.1016/j.rbmo.2018.01.014

48. Zhang P, Louhio H, Tuuri T, Sjöberg J, Hreinsson J, Telfer EE, et al. In vitro effect of cyclic adenosine 3', 5'-monophosphate (cAMP) on early human ovarian follicles. J Assist Reprod Genet. (2004) 21:301-6. doi: 10.1023/B:JARG.0000043704.10845.87

49. Asadi E, Najafi A, Moeini A, Pirjani R, Hassanzadeh G, Mikaeili S, et al. Ovarian tissue culture in presence of VEGF and fetuin stimulates follicle growth and steroidogenesis. J Endocrinol. (2017) 232:205-19. doi: 10.1530/JOE-16-0368

50. Cortvrindt R, Smitz J, van Steirteghem AC. In-vitro maturation, fertilization and embryo development of immature oocytes from early preantral follicles from prepuberal mice in a simplified culture system. Hum Reprod. (1996) 11:2656-66. doi: 10.1093/oxfordjournals.humrep.a019188

51. Spears N, Boland NI, Murray AA, Gosden RG. Mouse oocytes derived from in vitro grown primary ovarian follicles are fertile. Hum Reprod. (1994) 9:527-32. doi: 10.1093/oxfordjournals.humrep.a138539

52. Telfer EE, Binnie JP, McCaffery FH, Campbell BK. In vitro development of oocytes from porcine and bovine primary follicles. Mol Cell Endocrinol. (2000) 163:117-23. doi: 10.1016/S0303-7207(00)00216-1

53. Eppig John J,Schroeder Allen C. Capacity of mouse oocytes from preantral follicles to undergo embryogenesis and development to live young after growth, maturation, and fertilization in vitro. Biol Reprod. (1989) 41:268-76. doi: 10.1095/biolreprod41.2.268
54. Shiomi-Sugaya N, Komatsu K, Wang J, Yamashita M, Kikkawa F, Iwase A. Regulation of secondary follicle growth by theca cells and insulin-like growth factor 1. J Reprod Dev. (2015) 61:161-8. doi: 10.1262/jrd.2014-107

55. Demeestere I, Delbaere A, Gervy C, Van Den Bergh M, Devreker F, Englert Y. Effect of preantral follicle isolation technique on in vitro follicular growth, oocyte maturation and embryo development in mice. Hum Reprod. (2002) 17:2152-59. doi: 10.1093/humrep/17.8.2152

56. Kim EJ, Lee J, Youm HW, Kim SK, Lee JR, Suh CS, et al. Comparison of follicle isolation methods for mouse ovarian follicle culture in vitro. Reprod Sci. (2018) 25:1270-8. doi: 10.1177/1933719117737851

57. Li R, Albertini DF. The road to maturation: somatic cell interaction and self-organization of the mammalian oocyte. Nat Rev Mol Cell Biol. (2013) 14:141-52. doi: $10.1038 / \mathrm{nrm} 3531$

58. McLaughlin M, Bromfield JJ, Albertini DF, Telfer EE. Activin promotes follicular integrity and oogenesis in cultured pre-antral bovine follicles. Mol Hum Reprod. (2010) 16:644-53. doi: 10.1093/molehr/gaq021

59. Abir R, Franks S, Mobberley MA, Moore PA, Margara RA, Winston RM. Mechanical isolation and in vitro growth of preantral and small antral human follicles. Fertil Steril. (1997) 68:682-8. doi: 10.1016/S0015-0282(97)00264-1

60. Wang TR, Yan LY, Yan J, Lu CL, Xia X, Yin TL, et al. Basic fibroblast growth factor promotes the development of human ovarian early follicles during growth in vitro. Hum Reprod. (2014) 29:568-76. doi: 10.1093/humrep/det465

61. Xiao S, Zhang J, Romero MM, Smith KN, Shea LD, Woodruff TK. In vitro follicle growth supports human oocyte meiotic maturation. Sci Rep. (2015) 5:17323. doi: 10.1038/srep17323

62. Shea LD, Woodruff TK, Shikanov A. Bioengineering the ovarian follicle microenvironment. Annu Rev Biomed Eng. (2014) 16:29-52. doi: 10.1146/annurev-bioeng-071813-105131

63. Xu M, Barrett SL, West-Farrell E, Kondapalli LA, Kiesewetter SE, Shea LD, et al. In vitro grown human ovarian follicles from cancer patients support oocyte growth. Hum Reprod. (2009) 24:2531-40. doi: 10.1093/humrep/dep228

64. Heise M, Koepsel R, Russell AJ, McGee EA. Calcium alginate microencapsulation of ovarian follicles impacts $\mathrm{FSH}$ delivery and follicle morphology. Reprod Biol Endocrinol. (2005) 3:47. doi: 10.1186/1477-7827-3-47

65. Choi JK, Agarwal P, Huang H, Zhao S, He X. The crucial role of mechanical heterogeneity in regulating follicle development and ovulation with engineered ovarian microtissue. Biomaterials. (2014) 35:5122-8. doi: 10.1016/j.biomaterials.2014.03.028

66. Skory RM, Xu Y, Shea LD, Woodruff TK. Engineering the ovarian cycle using in vitro follicle culture. Hum Reprod. (2015) 30:1386-95. doi: 10.1093/humrep/dev052

67. Laronda MM, Rutz AL, Xiao S, Whelan KA, Duncan FE, Roth EW, et al. A bioprosthetic ovary created using $3 \mathrm{D}$ printed microporous scaffolds restores ovarian function in sterilized mice. Nat Commun. (2017) 8:15261. doi: $10.1038 /$ ncomms 15261

68. Pors SE, Ramlose M, Nikiforov D, Lundsgaard K, Cheng J, Andersen CY, et al. Initial steps in reconstruction of the human ovary: survival of pre-antral stage follicles in a decellularized human ovarian scaffold. Hum Reprod. (2019) 34:1523-35. doi: 10.1093/humrep/dez077

69. Tingen C, Kim A, Woodruff TK. The primordial pool of follicles and nest breakdown in mammalian ovaries. Mol Hum Reprod. (2009) 15:795-803. doi: $10.1093 / \mathrm{moleh} /$ gap073

70. Woodruff TK, Shea LD. A new hypothesis regarding ovarian follicle development: ovarian rigidity as a regulator of selection and health. J Assist Reprod Gen. (2011) 28:3-6. doi: 10.1007/s10815-010-9478-4

71. Cha KY, Koo JJ, Ko JJ, Choi DH, Han SY, Yoon TK. Pregnancy after in vitro fertilization of human follicular oocytes collected from nonstimulated cycles, their culture in vitro and their transfer in a donor oocyte program. Fertil Steril. (1991) 55:109-13. doi: 10.1016/S0015-0282(16)54068-0

72. Nogueira D, Sadeu JC, Montagut J. In vitro oocyte maturation: current status. Semin Reprod Med. (2012) 30:199-213. doi: 10.1055/s-0032-1311522

73. Chian RC, Uzelac PS, Nargund G. In vitro maturation of human immature oocytes for fertility preservation. Fertil Steril. (2013) 99:1173-81. doi: 10.1016/j.fertnstert.2013.01.141

74. Shirasawa H, Terada Y. In vitro maturation of human immature oocytes for fertility preservation and research material. Reprod Med Biol. (2017) 16:258-67. doi: $10.1002 / \mathrm{rmb} 2.12042$ 
75. Zou H, Chen B, Ding D, Gao M, Chen D, Liu Y. Melatonin promotes the development of immature oocytes from the $\mathrm{COH}$ cycle into healthy offspring by protecting mitochondrial function. J Pineal Res. (2020) 68:e12621. doi: 10.1111/jpi.12621

76. Zhang M, Su YQ, Sugiura K, Xia G, Eppig JJ. Granulosa cell ligand NPPC and its receptor NPR2 maintain meiotic arrest in mouse oocytes. Science. (2010) 330:366-9. doi: 10.1126/science.1193573

77. Nogueira D, Albano C, Adriaenssens T, Cortvrindt R, Bourgain C, Devroey $\mathrm{P}$, et al. Human oocytes reversibly arrested in prophase I by phosphodiesterase type 3 inhibitor in vitro. Biol Reprod. (2003) 69:1042-52. doi: 10.1095/biolreprod.103.015982

78. Nogueira D, Ron-El R, Friedler S, Schachter M, Raziel A, Cortvrindt R, et al. Meiotic arrest in vitro by phosphodiesterase 3-inhibitor enhances maturation capacity of human oocytes and allows subsequent embryonic development. Biol Reprod. (2006) 74:177-84. doi: 10.1095/biolreprod.105.040485

79. Shu YM, Zeng HT, Ren Z, Zhuang GL, Liang XY, Shen HW, et al. Effects of cilostamide and forskolin on the meiotic resumption and embryonic development of immature human oocytes. Hum Reprod. (2008) 23:504-13. doi: 10.1093/humrep/dem344

80. Sánchez F, Lolicato F, Romero S, De Vos M, Van Ranst H, Verheyen G, et al. An improved IVM method for cumulus-oocyte complexes from small follicles in polycystic ovary syndrome patients enhances oocyte competence and embryo yield. Hum Reprod. (2017) 32:2056-68. doi: 10.1093/humrep/dex262

81. Li Y, Liu H, Yu Q, Liu H, Huang T, Zhao S, et al. Growth hormone promotes in vitro maturation of human oocytes. Front Endocrinol. (2019) 10:485. doi: $10.3389 /$ fendo. 2019.00485
82. Chatroudi MH, Khalili MA, Ashourzadeh S, Anbari F, Shahedi A, Safari S. Growth differentiation factor 9 and cumulus cell supplementation in in vitro maturation culture media enhances the viability of human blastocysts. Clin Exp Reprod Med. (2019) 46:166-72. doi: 10.5653/cerm.2019.00402

83. Wang Q, Tang SB, Song XB, Deng TF, Zhang TT, Yin S, et al. High-glucose concentrations change DNA methylation levels in human IVM oocytes. Hum Reprod. (2018) 33:474-81. doi: 10.1093/humrep/ dey006

84. Nagashima JB, El Assal R, Songsasen N, Demirci U. Evaluation of an ovaryon-a-chip in large mammalian models: species specificity and influence of follicle isolation status. J Tissue Eng Regen Med. (2018) 12:e1926-35. doi: 10.1002/term.2623

85. Aziz AUR, Fu M, Deng J, Geng C, Luo Y, Lin B, et al. A microfluidic device for culturing an encapsulated ovarian follicle. Micromachines. (2017) 8:E335. doi: $10.3390 / \mathrm{mi} 8110335$

Conflict of Interest: The authors declare that the research was conducted in the absence of any commercial or financial relationships that could be construed as a potential conflict of interest.

Copyright (c) 2020 Yang, Zhu and Jin. This is an open-access article distributed under the terms of the Creative Commons Attribution License (CC BY). The use, distribution or reproduction in other forums is permitted, provided the original author(s) and the copyright owner(s) are credited and that the original publication in this journal is cited, in accordance with accepted academic practice. No use, distribution or reproduction is permitted which does not comply with these terms. 